\title{
Characteristics of patients transported by an air ambulance critical care team
}

\author{
Jacqueline A Catherall, ${ }^{1}$ Adam Brown, ${ }^{2}$ Jonathan R Benger ${ }^{3}$
}

${ }^{1}$ Medical School, University of Bristol, Bristol, UK

${ }^{2}$ Emergency Department, University Hospitals Bristol NHS Foundation Trust, Bristol, UK ${ }^{3}$ Academic Department of Emergency Care, University of the West of England, Bristol, UK

\section{Correspondence to}

Jacqueline Amber Catherall, Medical School, University of Bristol, 19 Hampton Road, Bristol BS6 6HW, UK; jacqueline.catherall@gmail.com

Accepted 27 April 2012

\section{ABSTRACT}

Background The aim of this study was to review patients conveyed by the Great Western Air Ambulance to its main receiving hospital.

Methods Retrospective data were collected for all patients transferred to Frenchay Hospital by the Great Western Air Ambulance between 1 June 2008 and 1 March 2010.

Results 115 patients were included in the review. Patients were conveyed up to $85 \mathrm{~km}, 79 \%$ bypassing the closest emergency department (ED). $51 \%$ of these patients had major trauma and $35 \%$ were intubated at the scene. On arrival, the mean time to CT scan was $78 \mathrm{~min}$, reduced to $63 \mathrm{~min}$ for those with a head injury. $16 \%$ of patients were discharged from the ED.

Conclusions This review provides an overview of the characteristics of patients transferred to a major receiving hospital by a prehospital critical care team.

\section{INTRODUCTION}

The Great Western Air Ambulance (GWAA) was launched in June 2008 and provides prehospital critical care to an area of South-West England, crewed by a pilot, doctor and 'critical care paramedic'. GWAA serves Avon, Gloucestershire, North Somerset and Wiltshire. ${ }^{1}$ Frenchay Hospital in Bristol is the main trauma hospital for the region, a tertiary centre for neurosurgery and the most common destination for GWAA.

The aim of this evaluation was to assess the characteristics of patients conveyed by GWAA to Frenchay Hospital during a 21-month period.

\section{METHODS}

Retrospective data were collected on all patients conveyed to the Frenchay Hospital by GWAA between 1 June 2008 and 1 March 2010. Information was obtained from the GWAA electronic clinical database, emergency department (ED) notes, ambulance patient care records, the hospital's patient information system and in some cases hospital notes.

\section{RESULTS}

During this time, GWAA transferred 117 patients to the Frenchay Hospital. In two cases insufficient information was available, leaving 115 patients for analysis.

\section{Demographics}

Patients were $68 \%$ male subjects, with a mean age of 35 years. The youngest patient was 11 months old, and the oldest was 88 years.

\section{Nature of incidents}

RTCs and falls accounted for over $60 \%$ of GWAA arrivals at Frenchay Hospital. Equestrian incidents $(11 \%)$ and medical calls $(7 \%)$ were the next most common.

\section{Location and distance}

The majority of patients (79\%) were taken to Frenchay Hospital rather than the closest ED. Overall, $65 \%$ of incident locations were within $30 \mathrm{~km}$ of Frenchay Hospital. A detailed map is shown in figure 1.

\section{Glasgow Coma Scale and rapid sequence induction of anaesthesia}

The initial Glasgow Coma Scale score and percentage of patients undergoing rapid sequence induction are shown in table 1. Intubation occurred in $35 \%$ of patients.

\section{Critical time management}

For all patients the mean scene time was $48 \mathrm{~min}$ (range 5-116 min), with patient entrapment or rapid sequence induction adding approximately 10 min each. The mean transfer time from scene to hospital was $11 \mathrm{~min}$ (range 2-35 min).

For patients requiring $\mathrm{CT}$ scan the mean time from arrival to CT was $78 \mathrm{~min}$ (range 19-212 min), decreasing to a mean of $63 \mathrm{~min}$ (range 19-135 min) for those with an apparent head injury.

A total of 16 patients went to theatre from the $\mathrm{ED}$; the mean time from arrival to theatre was 199 min (range 35 min-12 h 18 min).

\section{ISS and TRISS}

For all trauma patients, the mean Injury Severity Score (ISS) is shown in table 2. Fifty-nine patients $(51 \%)$ had major trauma (ISS $>16$ ).

The mean ISS for patients discharged from the ED was 8, and 18 for those admitted to orthopaedics.

Using TRISS methodology the probability of survival was calculated for 71 patients, including five out of six patients who died in the department. There were no unexpected deaths in the ED. Five further patients were not expected to survive, all of whom underwent emergency surgery. Three survived to discharge and two died.

\section{Onward disposal}

The onward destination for each patient leaving the ED is shown in figure 2.

Sixteen per cent of patients were discharged on the same day; this figure was $27 \%$ in a previous audit (J Dutson, unpublished data, 2008). For those admitted, the mean length of hospital stay was 15 days. 


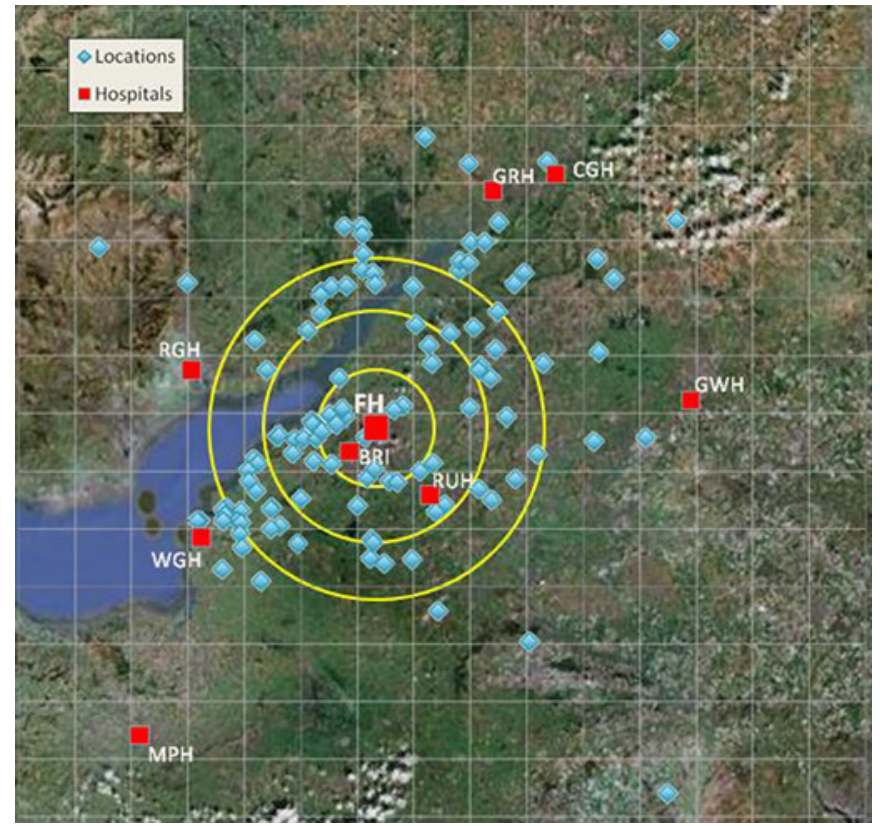

Figure 1 Map showing location of incidents and receiving hospitals. BRI, Bristol Royal Infirmary and Bristol Children's Hospital; CGH, Cheltenham General Hospital; FH, Frenchay Hospital; GRH, Gloucestershire Royal Hospital; GWH, Great Western Hospital, Swindon; MPH, Musgrove Park Hospital, Taunton; RGH, Royal Gwent Hospital; RUH, Royal United Hospital, Bath; WGH, Weston General Hospital.

\section{DISCUSSION}

This is the first review of patients transferred to a major UK receiving hospital by a newly-established prehospital critical care team led by a senior physician. ${ }^{2}{ }^{3}$ More than $50 \%$ of patients had major trauma, and the majority were conveyed to Frenchay Hospital, rather than the nearest ED. These data suggest appropriate on-scene decision-making and conveyance. There is potential to improve the time to imaging and/or theatre in those patients assessed prehospital by a senior clinician.

Table 1 Distribution of Glasgow Coma Scale (GCS) scores and percentage of patients undergoing prehospital rapid sequence induction of anaesthesia and tracheal intubation (RSI)

\begin{tabular}{lll}
\hline $\begin{array}{l}\text { Initial GCS } \\
\text { score }\end{array}$ & $\begin{array}{l}\text { Number (\%) } \\
\text { of patients }\end{array}$ & $\begin{array}{l}\text { Number }(\%) \text { of this } \\
\text { group undergoing RSI }\end{array}$ \\
\hline 3 & $12(10 \%)$ & $11(92 \%)$ \\
$4-9$ & $17(15 \%)$ & $14(82 \%)$ \\
$10-14$ & $20(17 \%)$ & $12(60 \%)$ \\
15 & $65(57 \%)$ & $3(5 \%)$ \\
\hline
\end{tabular}

Table 2 ISS and mortality data by mechanism of injury

\begin{tabular}{lllll}
\hline $\begin{array}{l}\text { Mechanism of injury } \\
\text { (no. of patients) }\end{array}$ & $\begin{array}{l}\text { Mean ISS } \\
\text { (range) }\end{array}$ & $\begin{array}{l}\text { No. of } \\
\text { patients } \\
\text { with ISS >16 }\end{array}$ & $\begin{array}{l}\text { No. of } \\
\text { patients } \\
\text { with ISS }>\mathbf{5 0}\end{array}$ & $\begin{array}{l}\text { No. of } \\
\text { patients } \\
\text { who died }\end{array}$ \\
\hline RTC (48) & $27(0-66)$ & 37 & 9 & 5 \\
Burns (5) & $21(10-41)$ & 3 & & \\
Fall (22) & $19(4-75)$ & 7 & 2 & 1 \\
Off-road (7) & $15(8-22)$ & 4 & & \\
Miscellaneous & $13(0-35)$ & 2 & & \\
trauma (7) & & & & \\
Horse (13) & $12(1-38)$ & 5 & 11 & 6 \\
Sport (5) & $6(4-16)$ & 1 & & \\
Total (107) & 21 & 59 & & \\
\hline
\end{tabular}

ISS, Injury Severity Score; RTC, road traffic collision.

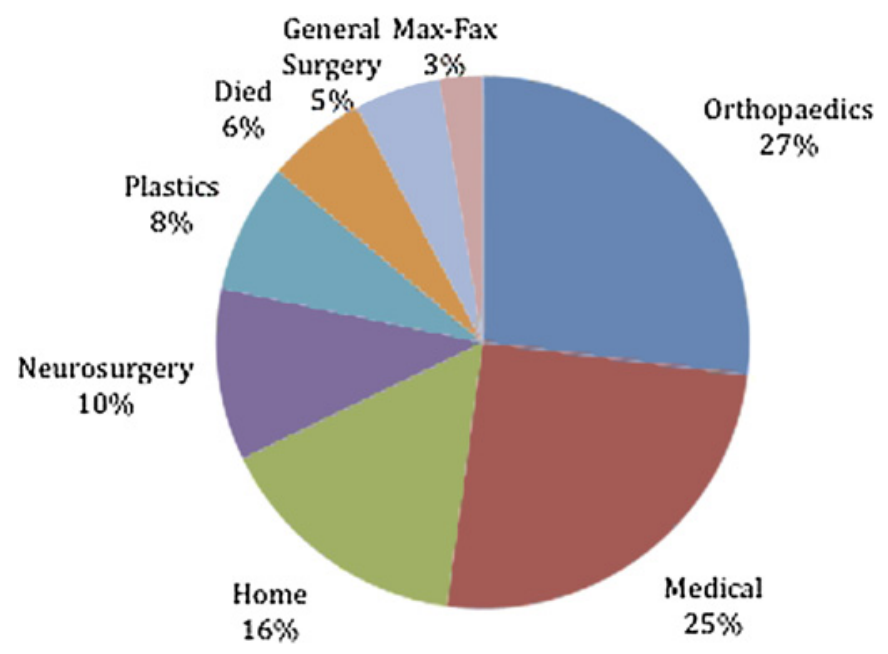

Figure 2 Pie chart showing patient disposal from the emergency department.

Contributors JAC conducted the data collection and analysis, and drafted and revised the paper. She is the guarantor. $A B$ initiated the project, monitored data collection and revised the draft paper. JRB drafted and revised the paper.

\section{Competing interests None.}

Provenance and peer review Not commissioned; externally peer reviewed.

\section{REFERENCES}

1. Great Western Air Ambulance Official Website. http://www. greatwesternairambulance.com/

2. Jenkinson $\mathbf{E}$, Currie $A$, Bleetman $A$. The impact of a new regional air ambulance service on a large general hospital. EMJ 2006:23:368-71.

3. Caldow SJ, Parke TRJ, Graham CA, et al. Aeromedical retrieval to a university hospital emergency department in Scotland. EMJ 2005;22:53-5. 


\section{EMJ}

\section{Characteristics of patients transported by an air ambulance critical care team}

Jacqueline A Catherall, Adam Brown and Jonathan R Benger

Emerg Med J published online May 29, 2012

doi: 10.1136/emermed-2011-200486

Updated information and services can be found at:

http://emj.bmj.com/content/early/2012/05/28/emermed-2011-200486.full.html

\section{These include:}

References This article cites 2 articles, 2 of which can be accessed free at: http://emj.bmj.com/content/early/2012/05/28/emermed-2011-200486.full.html\#ref-list-1

$\mathbf{P}<\mathbf{P} \quad$ Published online May 29, 2012 in advance of the print journal.

Email alerting Receive free email alerts when new articles cite this article. Sign up in service the box at the top right corner of the online article.

Topic
Collections

Articles on similar topics can be found in the following collections

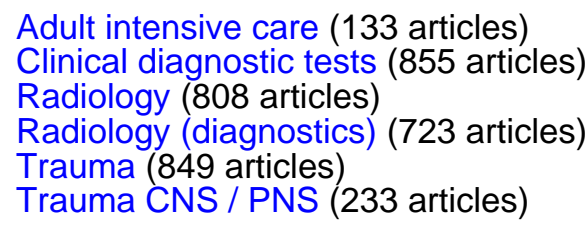

Advance online articles have been peer reviewed, accepted for publication, edited and typeset, but have not not yet appeared in the paper journal. Advance online articles are citable and establish publication priority; they are indexed by PubMed from initial publication. Citations to Advance online articles must include the digital object identifier (DOIs) and date of initial publication.

To request permissions go to:

http://group.bmj.com/group/rights-licensing/permissions

To order reprints go to:

http://journals.bmj.com/cgi/reprintform

To subscribe to BMJ go to:

http://group.bmj.com/subscribe/ 
Notes

Advance online articles have been peer reviewed, accepted for publication, edited and typeset, but have not not yet appeared in the paper journal. Advance online articles are citable and establish publication priority; they are indexed by PubMed from initial publication. Citations to Advance online articles must include the digital object identifier (DOIs) and date of initial publication.

To request permissions go to:

http://group.bmj.com/group/rights-licensing/permissions

To order reprints go to:

http://journals.bmj.com/cgi/reprintform

To subscribe to BMJ go to:

http://group.bmj.com/subscribe/ 